\title{
Pembelajaran Pengelolaan Keuangan Orang Tua, Uang Saku, Dan Hasil Belajar Terhadap Literasi Keuangan Di SMK PGRI 3 Sidoarjo
}

\author{
Is Rianda Megasari, Universitas Negeri Surabaya \\ rianda_imoetz@yahoo.co.id
}

\begin{abstract}
ABSTRAK
Penelitian ini bertujuan untuk menganalisis pengaruh pembelajaran pengelolaan keuangan orangtua terhadap hasil belajar, uang saku terhadap hasil belajar, pembelajaran pengelolaan keuangan orang tua terhadap literasi keuangan, uang saku terhadap literasi keuangan, hasil belajar terhadap literasi keuangan. Populasi penelitian adalah siswa kelas XI Akuntansi sebanyak 168 orang dan sampel 118 orang. Metode pengumpulan data angket dan dokumentasi dan teknik analisis digunakan SEM. Hasil penelitian menunjukkan pembelajaran pengelolaan keuangan orangtua berpengaruh terhadap hasil belajar, uang saku tidak berpengaruh terhadap hasil belajar, pembelajaran pengelolaan keuangan orangtua tidak berpengaruh terhadap literasi keuangan, uang saku berpengaruh terhadap literasi keuangan, hasil belajar berpengaruh terhadap literasi keuangan.

Kata Kunci: Pembelajaran Pengelolaan Keuangan Orangtua, Uang Saku, Hasil Belajar, Literasi Keuangan
\end{abstract}

\begin{abstract}
This research purposed to analyze the influence of parental financial management learning on learning outcomes, pocket money on learning outcomes, parental learning financial management on financial literacy, allowance on financial literacy, the result of learning on financial literacy. Population of this research a student of class XI Accountancy is 168 student and the sample is 118 student. The methods of data collection is questionnaire, documentation and analysis techniques used SEM. The results showed learning financial management parental influence learning outcomes, pocket money has no effect learning outcomes, learning financial management of the parents has no effect financial literacy, money pocket effect financial literacy, learning outcomes influence financial literacy.
\end{abstract}

Keywords: Parents Learning Financial Management, Pocket Money, Learning Outcomes, Literacy Financial

\section{PENDAHULUAN}

Indonesia yang memasuki era globalisasi, mengakibatkan kompleksitas berbagai jenis produk dan jasa yang ditawarkan oleh pasar semakin meningkat. Dari waktu kewaktu kehidupan dan pola keuangan masyarakat juga akan mengalami perubahan, yang awalnya bersikap sederhana berubah menjadi boros atau konsumtif dan Indonesia merupakan negara konsumtif kedua setelah Singapura, hal ini dapat dilihat dari tingkat nilai transaksi kartu kredit yang mencapai 250 triliun setahun (sumber : suara merdeka). 
Banyak orang mengalami kerugian finansial, sebagai akibat dari pengeluaran boros dan konsumsi, penggunaan bijaksana kredit kartu, menghitung perbedaan antara kredit konsumen dan pinjaman bank (Sulaeman \& Sandi, 2012). Orang-orang sering melakukan pembelian tanpa memperhatikan prinsip keuangan yaitu membeli barang dan jasa yang diinginkan (want) bukan dibutuhkan (need). Keputusan pembelian harus didasarkan pada logika bukan emosional semata. Pola perilaku keuangan yang cenderung boros hampir terjadi di semua lapisan masyarakat dengan kadar yang berbeda tak terkecuali siswa sekolah menengah ke atas yang tergolong masih remaja. Maka dari itu pengetahuan dan implementasi atas praktik keuangan pribadi yang sehat dan harus dimiliki oleh setiap orang. Sejauh mana pengetahuan dan implementasi seseorang atau masyarakat dalam mengelola keuangan pribadinya inilah yang dikenal dengan literasi (kemelekan) keuangan.

Namun di sisi lain remaja sebagai konsumen memiliki karakteristik mudah terpengaruh, mudah terbujuk iklan, tidak berpikir hemat dan realistik. Perilaku konsumtif pada kalangan remaja SMA/SMK terjadi karena usia remaja merupakan usia peralihan dalam mencari identitas diri sehingga remaja bersikap berlebihan. Jumlah populasi remaja dikalangan SMA/SMK dan fakta bahwa remaja kurang terampil dalam mengelola keuangan sehingga menyebabkan remaja menjadi target menarik bagi bermacam - macam bisnis yang ada. Dari fenomena tersebut, selama masa transisi dari remaja menuju dewasa awal, remaja harus memiliki suatu pengetahuan dasar mengenai keuangan yaitu literasi keuangan. Literasi keuangan bermanfaat untuk mencapai kesejahteraan keuangan dan hal ini tidak saja merupakan monopoli individu dewasa tetapi juga perlu diajarkan pada anak. (Danes dan Hira, dalam Jorgensen 2007) mengatakan, "Saya belajar bagaimana untuk mendapatkan pekerjaan dan menghasilkan uang, tetapi tidak ada yang pernah mengajari saya bagaimana mengelola uang. Belajar bagaimana mengelola uang adalah sama pentingnya dengan produktif'.

Literasi keuangan didefinisikan sebagai kemampuan untuk membuat penilaian informasi dan untuk mengambil keputusan yang efektif mengenai penggunaan dan pengelolaan uang (Australian Securities \& Investments Commission, 2003). Literasi keuangan dapat diartikan sebagai pengetahuan keuangan, dengan tujuan untuk mencapai kesejahteraan (Lusardi \& Mitchell, 2007). Menerapkan cara pengelolaan keuangan yang tepat, diharapkan seseorang bisa memperoleh manfaat yang maksimal dari uang yang dimilikinya. Literasi keuangan dapat dikatakan juga dengan kecerdasan Financial, yaitu kecerdasan dalam mengelola asset keuangan pribadi (Irin, 2012). Sedangkan menurut Mason dan Wilson (dalam Khrisna dkk, 2010) literasi keuangan didefinisikan sebagai kemampuan seseorang untuk mendapatkan, memahami, dan mengevaluasi informasi yang relevan untuk pengambilan keputusan dengan memahami konsekuensi finansial yang ditimbulkan. Literasi keuangan bisa dilihat dari pengganggaran, pinjamanm, tabungan dan investasi.

Berdasarkan pengamatan dilapangan literasi keuangan mereka dapat dilihat bagaimana mereka menabung uang di tabungan UPJ (unit penjualan jasa) sekolah, menginvestasikan uang untuk keperluan mendadak dalam bentuk deposit pulsa, dan sewaktu-waktu meminjam uang kepada teman jika saat membutuhkan, dan ketika menginginkan sesuatu tidak menggangarkan uang mereka sehingga cenderung meminta orang tua atau saudara. Siswa telah diajari bagaimana cara 
mengatur dan mempergunakan uang tetapi mereka masih membeli barang sesuai apa yang mereka inginkan bukan mereka butuhkan hal terlihat dengan perilaku mereka. Uang saku yang diterima dari orang tua habis digunakan untuk membeli jajan dan transportasi. Pemberian uang saku pun beragam ada yang harian, mingguan, bulanan (Rina,2004).

Cude at el (2006) menyatakan bahwa orang tua merupakan peranan yang sangat penting dalam proses sosialisasi keuangan anak. Irin (2012) menyatakan pembelajaran keuangan keluarga dititik beratkan kepada pemahaman tentang nilai uang dan penanaman sikap serta perilaku anak untuk dapat mengatur pemanfaatan uang. Sulaeman (2012) orang tua merupakan sumber yang paling penting dari pengetahuan tentang pengelolaan pribadi keuangan, yang berarti orang tua harus memberi contoh kepada responden dalam manajemen keuangan pribadi. Oleh karena itu, orang tua harus aktif memberikan keuangan pendidikan anak-anak mereka dan orang tua harus mengetahui dan memahami perkembangan produk dan jasa keuangan. Orang tua perlu sadar bahwa perannya dalam pembelajaran keuangan pada mengelola uang merupakan salah satu penentu kesuksesan anak di masa mendatang, dimana dalam konteks keuangan anak dapat menjadi pribadi yang mandiri.

Faktor yang berperan lainnya adalah uang saku. Uang saku merupakan sumber pendapatan terbesar siswa. Sulaeman (2012) menjelaskan uang saku mempunyai pengaruh yang signifikan kepada literasi keuangan. Rina (2004) mengatakan memberikan uang saku akan memberikan dasar pengelolaan uang yang baik, karena hal ini memberikan kesempatan bagi para orang tua untuk mengembangkan kebiasaan baik pada anak. Menurut Apri (2012) pemberian uang saku juga memberikan pengaruh terhadap prestasi belajar siswa. Jadi uang saku selain mempengaruhi literasi keuangan juga akan mempengaruhi hasil belajar. Selain pembelajaran keuangan orang tua dan pemberian uang saku. Faktor lain yang menarik adalah hasil belajar.

Hasil belajar akuntansi merupakan gambaran tingkat pemahaman pengetahuan siswa terhadap konsep dasar akuntansi yang mereka terima disekolah. Menurut Mujiono (dalam Muizzatu, 2013) hasil belajar merupakan hasil proses belajar atau prose pembelajaran. Dimana pelaku aktif dalam belajar adalah siswa sedangkan pelaku aktif pembelajaran adalah guru. Hasil belajar akuntansi merupakan gambaran tingkat pemahaman siswa pada konsep - konsep dasar akuntansi yang mereka terima disekolah. Secara logika tingkat pemahaman pengetahuan yang baik akuntansi disekolah akan berpengaruh baik terhadap pengaplikasian dalam kehidupan keuangan mereka. Sebaliknya, tingkat pemahaman pengetahuan yang kurang baik tentang akuntansi akan berpengaruh kurang baik pengaplikasian dalam kehidupan keuangan mereka. Hasil belajar dipengaruhi faktor intern dan ekstern. Peran sosialisasi awal yang dimiliki oleh orang tua secara unik mempengaruhi hasil belajar keuangan remaja yang beranjak dewasa. Wahyono (2001). Orang tua yang memberikan pembelajaran keuangan dikeluarga secara tidak langsung akan memberikan dampak pengetahuan yang nantinya membantu siswa memahami pengetahuan akuntansi. Hasil belajar juga dipengaruhi oleh pemberian uang saku yang diberikan Orang tua bisa beragam tergantung dari besar kecilnya pendapatan Orang tua. Apri (2012) mengatakan uang saku akan memberikan pengaruh terhadap hasil belajar anak. 
Peneliti menemukan perbedaan yang menjadi masalah dalam penelitian ini yaitu perbedaan yang ada pada Ayu khrisna (2012) menjelaskan variabel hasil belajar tidak memiliki pengaruh terhadap literasi keuangan. Ayu menjelaskan responden yang memiliki IPK $<3$ memiliki literasi keuangan yang lebih tinggi dibandingkan dengan responden yang memiliki IPK > 3. Sulaeman (2012) menjelaskan IPK tidak berpengaruh secara signifikan terhadap literasi keuangan .

Pentingnya penelitian ini dilakukan untuk mengkaji lebih dalam pengaruh pembelajaran pengelolaan keuangan Orang tua, uang saku, hasil belajar yang pada akhirnya dapat diketahui faktor dominan yang mempengaruhi hasil belajar dan literasi keuangan. Sehingga dapat menjadi bahan masukan bagi berbagai pihak khususnya sekolah dan keluarga guna meningkatkan hasil belajar dan literasi keuangan siswa.

\section{METODE PENELITIAN}

Pendekatan yang digunakan dalam penelitian ini adalah pendekatan kuantitatif sedangkan variabel dalam penelitian ini adalah Pembelajaran pengelolaan keuangan orang tua, uang saku, hasil belajar sebagai variabel independen sedangkan hasil belajar dan literasi keuangan sebagai variabel dependen. Populasi dalam penelitian ini seluruh siswa kelas XI Akuntansi SMK PGRI 3 Sidoarjo berjumlah 168 siswa. Sampel penelitian sebesar 118 siswa. Teknik sampling yang digunakan teknik propotional random sampling.

Metode pengumpulan data yang digunakan dalam penelitian ini adalah Angket dan dokumentasi. Teknik analisis data yang digunakan dalam penelitian ini adalah SEM (Structural Equation Modelling).

Spesifikasi model antar variabel digambarkan pada gambar dibawah ini.

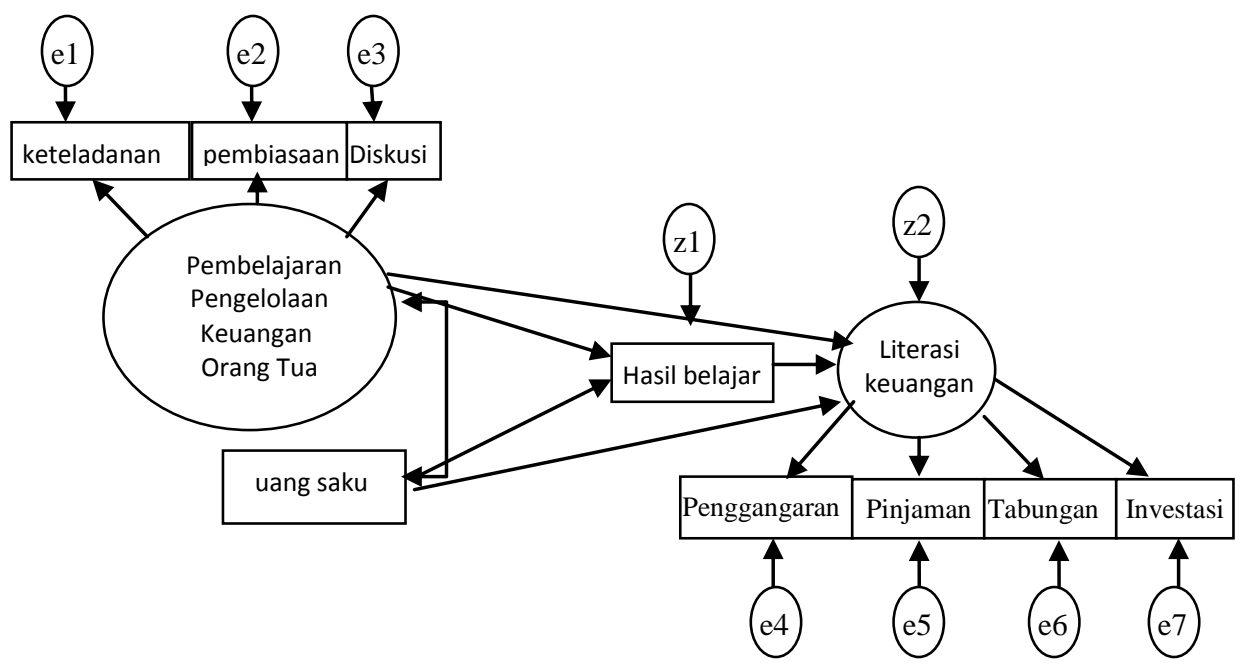

Gambar 1 Model antar variabel

\section{HASIL PENELITIAN DAN PEMBAHASAN}

\section{Hasil Penelitian}

Berdasarkan Uji normalitas (assessment of normality), nilai Univariate $1,518<2.58$ dan nilai multivariate $0,586<2,58$ dengan signifikan 0,01 bahwa 
dikatakan normal. Hasil Uji outliet diperoleh hasil bahwa outier univariate Z-score tidak melebihi kisaran 4 dan uji multivariate outliet memiliki nilai 23,668 < 27,877 tidak ada multivariate. Hasil uji Multicollinearty dan Singularity dengan nilai determinan kovarians matrik 0,005 tidak terjadi adanya multiklinieritas. Hasil uji Goodness Of Fit Index dengan nilai $X^{2}$-chi-square nilai 18,467 , Significant Probability 0,732 $\geq 0,05$, CMIN/DF $1,063 \leq 2,00$, GFI $0,967 \geq 0,90$, AGFI $0,935 \geq 0,90$, TLI $1,064 \geq 0,95$, CFI $1,000 \geq 0,95$,RMSEA $0,000 \leq 0,08$ Berdasarkan uji goodness of fit disimpulkan model dapat diterima, hipotesis nol yang menyatakan tidak terdapat perbedaan matriks kovarians sampel dan matriks kovarians populasi yang diestimasi diterima.

Pengaruh efek langsung dan tidak langsung disajikan pada tabel dibawah ini.

Tabel 1

Nilai koefisien SEM Pengaruh Antar Variabel

\begin{tabular}{|l|c|c|}
\hline \multicolumn{1}{|c|}{ Hubungan Kausalitas } & \multirow{2}{*}{$\begin{array}{c}\text { Direct } \\
\text { Effect }\end{array}$} & Indirect Effect \\
\cline { 3 - 3 } & $-0,690$ & Hasil Belajar \\
\hline Pemb.Pengel.Keu OT $\rightarrow$ Hasil Belajar & $-0,109$ & - \\
\hline Uang saku $\rightarrow$ Hasil Belajar & $-0,249$ & 0,087 \\
\hline Pemb.Pengel.Keu OT $\rightarrow$ Literasi Keuangan & $-0,230$ & 0,014 \\
\hline Uang saku $\rightarrow$ Literasi Keuangan & $-0,126$ & - \\
\hline Hasil Belajar $\rightarrow$ Literasi Keuangan &
\end{tabular}

Sumber: data diolah

Dari tabel tersebut diatas, maka diketahui bahwa :

1. Variabel yang paling berpengaruh terhadap hasil belajar adalah uang saku karena memiliki koefisien negatif terbesar, selanjutnya pembelajaran pengelolaan keuangan Orang tua

2. Variabel yang paling berpengaruh terhadap literasi keuangan adalah hasil belajar karena memiliki koefisien negatif terbesar, selanjutnya Uang saku dan pembelajaran pengelolaan keuangan Orang tua.

3. Pengaruh tidak langsung (Indirect Effect) pembelajaran pengelolaan keuangan orang tua, uang saku melalui hasil belajar, memiliki koefisien terbesar adalah pembelajaran pengelolaan keuangan Orang tua.

Pengaruh antar variabel dan Pengujian Hipotesis antar variabel disajikan pada tabel dibawah ini:

Tabel 2 Uji Kausalitas regression weight

\begin{tabular}{|l|c|c|c|c|c|}
\hline \multicolumn{1}{|c|}{ Hubungan kausalitas } & Estimate & $\begin{array}{c}\text { Std } \\
\text { Estimate }\end{array}$ & S.E. & C.R. & P-Value \\
\hline Pemb.Keu OT $\rightarrow$ Hasil Belajar &,- 690 &,- 350 &, 287 & $-2,403$ &, 016 \\
\hline Uang Saku $\rightarrow$ Hasil Belajar &,- 109 &,- 111 &, 089 & $-1,219$ &, 223 \\
\hline Pemb.keu OT $\rightarrow$ Literasi keu &,- 249 &,- 136 &, 285 &,- 874 &, 382 \\
\hline Uang saku $\rightarrow$ Literasi Keu &,- 203 &,- 224 &, 097 & $-2,094$ &, 036 \\
\hline Hasil Belajar - Literasi Keu &,- 126 &,- 136 &, 109 & $-1,162$ &, 245 \\
\hline
\end{tabular}

Sumber: Data Diolah

Berdasarkan tabel diatas diperoleh hasil sebagai berikut:

1. Hipotesis 1 : Pembelajaran Pengelolaan Keuangan Orang tua Berpengaruh Terhadap Hasil belajar 
Hasil estimasi parameter variabel Pembelajaran Pengelolaan Keuangan Orang tua terhadap hasil belajar menunjukkan nilai signifikan dengan nilai nilai C.R -2,403 lebih besar dari -2,00. Disamping itu diperoleh nilai taraf signifikan $0,016(\mathrm{p} \leq 0,05)$. Sehingga hipotesis pertama yang menjelaskan bahwa pembelajaran pengelolaan keuangan Orang tua berpengaruh terhadap hasil belajar, terbukti kebenarannya

2. Hipotesis 2 : Uang saku berpengaruh terhadap hasil belajar

Hasil estimasi parameter variabel uang saku terhadap hasil belajar menunjukkan nilai signifikan dengan nilai nilai C.R -1,219 kurang dari -2,00. Disamping itu diperoleh nilai taraf signifikan 0,223 ( $p \geq 0,05)$. Sehingga hipotesis kedua yang menjelaskan bahwa uang saku berpengaruh terhadap hasil belajar, tidak terbukti kebenarannya

3. Hipotesis 3 : Pembelajaran pengelolaan keuangan Orang tua berpengaruh terhadap literasi keuangan

Hasil estimasi parameter variabel pengelolaan keuangan Orang tua terhadap literasi keuangan menunjukkan nilai signifikan dengan nilai nilai C.R $-0,874$ kurang dari $-2,00$. Disamping itu diperoleh nilai taraf signifikan 0,382 $(\mathrm{p} \geq 0,05)$. Sehingga hipotesis ketiga yang menjelaskan bahwa Pembelajaran pengelolaan keuangan Orang tua berpengaruh terhadap literasi keuangan, tidak terbukti kebenarannya

4. Hipotesis 4 : Uang saku Berpengaruh terhadap literasi keuangan

- Hasil estimasi parameter variabel Pembelajaran uang saku terhadap literasi keuangan menunjukkan nilai signifikan dengan nilai nilai C.R -2,094 lebih besar dari -2,00. Disamping itu diperoleh nilai taraf signifikan 0,036 $(\mathrm{p} \leq 0,05)$. Sehingg hipotesis keempat yang menjelaskan bahwa uang saku berpengaruh terhadap literasi keuangan, terbukti kebenarannya

5. Hipotesis 5 : Hasil belajar berpengaruh terhadap literasi keuangan

. Hasil estimasi parameter variabel hasil belajar terhadap literasi keuangan menunjukkan nilai signifikan dengan nilai nilai C.R -1,162 kurang dari -2,00. Disamping itu diperoleh nilai taraf signifikan 0,223 ( $\mathrm{p} \geq 0,05)$. Sehingga hipotesis kelima yang menjelaskan bahwa Hasil belajar berpengaruh terhadap literasi keuangan, tidak terbukti kebenarannya

\section{Pembahasan}

\section{Pengaruh Pembelajaran Pengelolaan Keuangan Orang Tua (PPKO)} Terhadap Hasil belajar akuntansi .

Berdasarkan hasil analisis data terdapat pengaruh yang signifikan dan terdapat hubungan yang negative antara pembelajaran pengelolaan keuangan orang tua dengan hasil belajar akuntansi. Pengertian semakin negative atau rendah pembelajaran pengelolaan keuangan orang tua akan diiringi dengan meningkatnya hasil belajar akuntansi. Demikian pula sebaliknya semakin positif atau tinggi pembelajaran pengelolaan keuangan orang tua akan diiringi dengan menurunnya hasil belajar akuntansi.

Berdasarkan hasil analisis data efek langsung pembelajaran pengelolaan keuangan orang tua memiliki pengaruh terbesar kepada tiap indikatornya adalah diskusi. Pembelajaran pengelolaan keuangan orang tua memiliki efek langsung dan tidak memiliki efek tidak langsung atau perantara ke hasil belajar. 
Berdasarkan hasil penelitian yang diskusi memiliki nilai yang terbesar karena diskusi merupakan hal yang penting, hal ini didukung dengan Schaefer dan Digeromino dalam wahyono (2001), mengungkapan pentingnya sekali mengkomunikasikan mengenai hal-hal yang dianggap penting kepada anak-anak dalam upaya mendidik anak. Jorgensen (2007) juga mendukung diskusi secara langsung akan meningkatkan pengetahuan, sikap, nilai dan perilaku. Keluarga memiliki peranan penting dalam upaya mengembangkan pribadi anak. Orang tua mempunyai tugas sebagai pendidik dan keluarga merupakan lingkungan yang paling bertanggung jawab mendidik anak-anaknya. Pola, sikap, perilaku dan nilainilai yang ditanamkan orang tua merupakan landasan bagi perkembangan keperibadian anak dan tingkah laku selanjutnya.

Berdasarkan hasil pembahasan pembelajaran pengelolaan keuangan orang tua tergolong sedang atau terkadang dilakukan. Lingkungan keluarga merupakan lingkungan pertama dan utama pembentuk keterampilan anak, keteladanan yang diperoleh oleh anak dan keluarganya mempengaruhi pembentukan perilaku anak (suwarno, dalam susanti 2013). Walaupun pembelajaran pengelolaan keuangan orang tua tidak sering dilakukan tetapi pada faktor lingkungan disekolah baik dari pihak pembelajaran disekolah maupun teman sebaya juga memberikan dampak pada hasil belajar akuntansi mereka. Pengetahuan sebagai hasil pembelajaran disekolah sangat terkait dengan proses belajar mengajar disekolah. Proses pembelajaran dilakukan oleh guru sangat menentukan keberhasilan siswa dalam memahami dan mengimplementasikan materi yang diterima dalam kehidupan (trianto,dalam susanti 2013). Pembelajaran disekolah yang ada dari guru mata pelajaran akuntansi, pembelajaran yang dilakukan sudah baik dan anak-anak juga bisa saling bertukar pendapat berkaitan pelajaran akuntansi baik dengan teman sebaya atau bertanya kepada guru. Terlihat dengan anak - anak menerima pembelajaran akuntansi dengan serius dan saling mendiskusikan tugas dengan teman ketika mengerjakan tugas yang diberikan guru.

Temuan Penelitian ini juga didukung oleh Slameto (2003) mengatakan hasil belajar dipengaruhi oleh beberapa faktor baik faktor intern maupun ekstern, Faktor selain lingkungan keluarga diantaranya lingkungan sekolah, lingkungan sekolah bisa dari pihak guru, metode pembelajaran dan teman. Hal ini juga didukung dengan penelitian terdahulu oleh Devie (2011) mengatakan guru sangat berperan penting dalam keberhasilan hasil belajar siswa, Ainil (2007) teman sebaya memberikan pengaruh terhadap hasil belajar akuntansi.

Sehingga Lingkungan sekolah, masyarakat dan teman sebaya memberikan pengaruh terhadap hasil belajar selain pembelajaran pengelolaan keuangan diberikan orang tua kepada siswa. Penting guru tetap mempertahankan metode pembelajaran guna meningkatkan hasil belajar siswa.

\section{Pengaruh Uang Saku Terhadap Hasil Belajar Akuntansi}

Berdasarkan hasil analisis data terdapat pengaruh yang tidak signifikan dan terdapat hubungan yang negatif antara uang saku dengan hasil belajar akuntansi. Hal ini memberikan pengertian semakin negative atau rendah uang saku akan diiringi dengan meningkatnya hasil belajar akuntansi. Demikian pula sebaliknya semakin positif atau tinggi uang saku akan diiringi dengan menurunnya hasil belajar akuntansi.

Hasil analisis data diperoleh hasil terdapat efek langsung antara uang saku terhadap hasil belajar akuntansi dan tidak terdapat efek tidak langsung artinya 
tidak memiliki efek tidak langsung atau perantara dan efek total terhadap hasil belajar akuntansi.

Penelitian yang dilakukan ini tidak sesuai dengan penelitian terdahulu yaitu Astuti (2012) yang menyimpulkan bahwa uang saku berpengaruh siginifikan dan positif terhadap prestasi belajar.

Karena tidak sesuai dengan atau kebalikan dengan penelitian sebelumnya yang menyebutkan semakin tinggi uang saku maka akan semakin tinggi hasil belajar yang dicapai. Tidak adanya pengaruh signifikan dalam penelitian ini dapat disebabkan oleh berbagai faktor baik dari siswa sendiri, lingkungan maupun keluarga

Berdasarkan hasil penelitian yang ada anak - anak memiliki uang saku yang berbeda, uang saku yang mereka peroleh mereka pergunakan untuk membeli makanan dan minuman. Penggunaan uang saku penting adanya dalam menunjang keberhasilan hasil belajar. Siswa yang mempergunakan uang saku dengan semaunya memberikan dampak yang tidak baik dalam belajarnya. Penggunaan uang saku yang tidak baik juga bisa disebabkan rendahnya pendidikan pengelolaan keuangan orang tua yang rendah sehingga anak cenderung konsumtif dalam membeli barang.

Slameto (2003) mengatakan hasil belajar dipengaruhi oleh beberapa faktor baik faktor intern maupun ekstern, faktor selain lingkungan keluarga, lingkungan sekolah, lingkungan masyarakat. Jika anak dikeliling lingkungan yang tidak dapat mengatur penggunaan uang maka akan berdampak siswa menjadi konsumtif dan anak cenderung tidak belajar yang dapat mengakibatkan menurunnya hasil belajar akuntansi.

Seharusnya seorang siswa akan mengetahui pentingnya pengelolaan uang saku tersendiri. Karena siswa yang dapat mengelola uang untuk kebutuhan belajar baik untuk membeli alat tulis atau buku dapat menambah pengetahuan yang nantinya meningkatkan hasil belajar akuntansi. Uang saku siswa adalah uang yang diperoleh siswa pada saat berangkat sekolah. Uang saku ini bisa diberi oleh orang tua, saudara, kakek,dll. Besar uang saku siswa sesuai dengan kemampuan orang tua. Uang saku bisa diperoleh setiah hari, mingguan, dll bergantung pemberian orang tua. berdasarkan hasil pembahasan uang saku siswa kelas XI akuntansi tergolong dengan nilai sedang.

Data Responden menyebutkan sebagian besar siswa adalah perempuan dan sisanya laki-laki, yang berarti penggunaan uang mereka kurang begitu terkontrol. Sebaliknya disisi lain hasil belajar akuntansi dicapai oleh siswa dipengaruhi oleh faktor yang berada dalam diri invidu yang sedang belajar terutama kemampuan yang dimilikinya. Faktor kemampuan dalam diri siswa berpengaruh terhadap hasil belajar akuntansi yang dicapai dari pada yang berasal dari luar diri siswa dalam hal ini adalah uang saku. Hal ini sesuai dengan disampaikan Suryabrata (2004) dan Dalyono (2004) menyatakan prestasi yang diperoleh seorang diperoleh faktor internal yang berasal dari diri siswa. Atas dasar kemampuan yang berasal dari siswa sendiri, siswa dapat meraih hasil belajar akuntansi yang dicapai sehingga faktor uang saku tidak berdampak pengaruhnya.

Sehingga dapat dikatakan uang saku siswa tidak bisa menjamin meningkatkan prestasi siswa, karena tidak sesuai dengan atau kebalikan dengan penelitian sebelumnya yang menyebutkan semakin tinggi uang saku maka akan semakin tinggi prestasi belajar yang dicapai. Tidak adanya pengaruh signifikan 
dalam penelitian ini dapat disebabkan oleh berbagai faktor baik dari siswa, keluarga, maupun dari lingkungan sekitar.

Dari hasil temuan penelitian ini ada beberapa faktor lain yang dapat mempengaruhi hasil belajar akuntansi di SMK PGRI 3 Sidoarjo yaitu berasal dari Internal siswa maupun eksternal yaitu lingkungan sekolah dan teman sebaya.

\section{Pengaruh Pembelajaran Pengelolaan Keuangan Orang Tua Terhadap Literasi Keuangan}

Berdasarkan hasil analisis data menunjukkan terdapat pengaruh yang tidak signifikan dan terdapat hubungan yang negative antara pembelajaran pengelolaan keuangan orang tua dengan literasi keuangan. Hal ini memberikan pengertian semakin negative atau rendah pembelajaran pengelolaan keuangan orang tua akan diiringi dengan meningkatnya literasi keuangan. Demikian pula sebaliknya semakin positif atau tinggi pembelajaran pengelolaan keuangan orang tua akan diiringi dengan menurunnya literasi keuangan.

Hasil analisis data menunjukkan efek langsung pembelajaran pengelolaan keuangan orang tua memiliki pengaruh terbesar kepada tiap indikatornya adalah diskusi dan terdapat efek langsung Literasi keuangan kepada tiap indikator adalah investasi. Hasil pembahasan Terdapat efek langsung dan tidak langsung antara pembelajaran pengelolaan keuangan orang tua kepada literasi keuangan. Pembelajaran pengelolaan keuangan orang tua memiliki efek langsung ke literasi keuangan, Pembelajaran pengelolaan keuangan orang tua memiliki efek tidak langsung melalui hasil belajar terhadap literasi keuangan dan efek total sebesar terhadap literasi keuangan.

Berdasarkan pengaruh efek langsung nilai terbesar dari faktor literasi keuangan adalah investasi, investasi merupakan bagian dari tabungan yang digunakan untuk menghasilkan barang dan jasa yang bertujuan memebrikan keuntungan. Mereka sering menginvestasikan uang mereka dalam bentuk benda misalnya membeli emas yang nantinya ketika membutuhkan uang dapat mereka jual kembali. Dengan adanya faktor tersebut ketika mereka memiliki uang mereka belikan benda tersebut.

Orang tua memiliki peran penting dalam mempengaruhi perilaku konsumen anak-anak. Dalam Jorgensen (2007) ditemukan siswa yang belajar tentang mengelola keuangan pada orang tua mereka memiliki pengetahuan financial yang lebih tinggi daripada siswa yang tidak belajar tentang mengelola keuangan pada orang tua mereka. Cude et al (2006) menyatakan bahwa orang tua memainkan peranan yang sangat penting dalam proses sosialisasi keuangan anak-anak mereka

Keadaan ini berbalik dengan penelitian terdahulu Jorgensen (2010), Sulaeman (2012), Cude dkk (2006), irin (2012), Susanti (2013) yang menyatakan peran orang tua dalam memberikan pembelajaran pengelolaan keuangan di keluarga memberikan pengaruh signifikan terhadap literasi keuangan.

Karena tidak sesuai dengan atau kebalikan dengan penelitian sebelumnya yang menyebutkan semakin tinggi pembelajaran pengelolaan keuangan orang tua maka akan semakin tinggi literasi keuangan yang dicapai. Tidak adanya pengaruh signifikan dalam penelitian ini dapat disebabkan oleh berbagai faktor baik dari siswa sendiri, lingkungan maupun keluarga.

Pembelajaran pengelolaan keuangan orang tua yang dilakukan tidak terlalu sering dan tidak memberikan pengaruh terhadap literasi keuangan dikarenakan ada beberapa alasan lain. Setelah diadakan pengamatan dilapangan hal ini 
dikarenakan orang tua kurang memberikan pembelajaran keuangan sehingga siswa tidak begitu memahami literasi keuangan, selain peran orang tua ada juga pembelajaran dilakukan disekolah. Pembelajaran keuangan sangat berperan penting dalam proses pembentukan literasi keuangan melalui kombinasi berbagai metode pembelajaran, media dan sumber belajar sebagai bekal yang mampu menghadapi kehidupan mereka saat ini maupun masa depan yang semakin komplek (Lutfi\&Iramani dalam susanti). Proses pembelajaran dan teknik evaluasi guru sangat menentukan keberhasilan siswa dalam memahami dan mengimplementasikan materi dalam kehidupan serhari-hari (Trianto,2009) Pembelajaran disekolah siswa diajarkan materi akuntansi yang nantinya siswa memahami pengelolaan uang walaupun tidak mendapat pembelajaran pengelolaan keuangan dari orang tua siswa diajarkan tentang akuntansi. Teman sebaya juga memberikan dampak terhadap literasi keuangan siswa, karena denga siapa kita berteman akan mempengaruhi perilaku kita dalam mengelola keuangan hal ini didukung dengan penelitian Susanti (2013).

Dari hasil temuan penelitian ini selain pendidikan keuangan kelurga, sekolah dan teman sebaya memberikan pengaruh kepada literasi keuangan siswa. maka pentingnya pembelajaran keuangan disekolah semakin ditingkatkan dan pemilihan teman sebaya.

\section{Pengaruh Uang Saku Terhadap Literasi Keuangan}

Berdasarkan hasil analisis data diperoleh hasil terdapat pengaruh yang signifikan dan terdapat hubungan yang negative antara uang saku dengan literasi keuangan. Hal ini memberikan pengertian semakin negative atau rendah uang saku akan diiringi dengan meningkatnya literasi keuangan. Demikian pula sebaliknya semakin positif atau tinggi uang saku akan diiringi dengan menurunnya literasi keuangan.

Hasil analisis data menunjukkan terdapat efek langsung Literasi keuangan kepada tiap indikator. Berdasarkan hasil efek langsung literasi keuangn yang memiliki pengaruh terbesar adalah investasi. Terdapat efek langsung dan efek tidak langsung antara uang saku kepada literasi keuangan. Uang saku memiliki efek langsung ke literasi keuangan, uang saku memiliki efek tidak langsung melalui hasil belajar terhadap literasi keuangan dan efek total sebesar terhadap literasi keuangan.

Keadaan ini mendukung penelitian sebelumnya Sulaeman (2012), yang mengatakan uang saku mempengaruhi literasi keuangan. Rini (2004) mengatakan pengelolaan uang saku yang baik akan membuat anak bisa mengelola uang demi masa depannya.

Berdasarkan hasil pengamatan yang ada anak - anak memperoleh uang saku yang berbeda hal ini disebabkan tingkat pendapatan orang tua mereka berbeda, uang saku yang mereka peroleh mereka pergunakan untuk membeli makanan dan minuman. Penerimaan uang saku mereka membuat mereka semakin boros dalam membeli barang. Apalagi dengan data yang diperoleh anak-anak memperoleh uang saku dari orang tua, kakek nenek dan saudara. Keluarga memiliki peranan penting dalam upaya mengembangkan pribadi anak. Orang tua mempunyai tugas sebagai pendidik dan keluarga merupakan lingkungan yang paling bertanggung jawab mendidik anak-anaknya. Pola, sikap, perilaku dan nilai-nilai yang ditanamkan orang tua merupakan landasan bagi perkembangan keperibadian anak dan tingkah laku selanjutnya. Lingkungan keluarga merupakan lingkungan 
pertama dan utama pembentuk keterampilan anak, keteladanan yang diperoleh oleh anak dan keluarganya mempengaruhi pembentukan perilaku anak (suwarno, dalam susanti 2013). Pendidikan keuangan dikeluarga yang rendah membuat anak tidak bisa mengelola uang saku dengan baik Pemberian uang saku ini diberikan hampir tiap hari. Dijaman yang semakin berkembang dengan banyak barang yang ada membuat anak-anak sekolah menjadi sasaran dalam penjualan mereka. Apalagi jika tidak adanya control pengelolaan uang dari keluarga. Karena keluarga memegang peranan yang cukup penting dalam mengajari anak dalam mengelola uang. Teman sebaya mereka juga memiliki peran siswa dalam penggunaan uang saku mempengaruhi literasi keuangan mereka. Jika seorang anak berteman dengan seseorang yang suka berbelanja akan membuat mereka menjadi seperti itu dan jika mereka berteman dengan orang yang bisa mengatur uang maka mereka akan menjadi seorang pengatur uang.

Hal ini didukung oleh penelitian terdahulu Jorgensen (2010), Cude et(2006) Susanti (2013), Johson\&Margareth (2007), Gutter\&De Vaney (2008) mengatakan bahwa pengelolaan keuangan keluarga dan teman sebaya memiliki pengaruh terhadap literasi keuangan siswa.

Dari hasil temuan penelitian ini pentingnya pendidikan pengelolaan keuangan keluarga untuk memberikan pendidikan keuangan siswa dalam mengatur uang saku sehingga siswa tidak cenderung konsumtif dan memilih teman sebaya dalam pergaulan karena dengan pemilihan teman yang salah akan mempengaruhi literasi keuangan siswa.

\section{Pengaruh Hasil Belajar Akuntansi Terhadap Literasi Keuangan}

Berdasarkan hasil analisis data diperoleh hasil tidak terdapat pengaruh signifikan dan terdapat hubungan yang negative antara hasil belajar akuntansi dengan literasi keuangan. Hal ini memberikan pengertian semakin negative atau rendah hasil belajar akuntansi akan diiringi dengan meningkatnya literasi keuangan. Demikian pula sebaliknya semakin positif atau tinggi hasil belajar akuntansi akan diiringi dengan menurunnya literasi keuangan. diperoleh hasil terdapat efek langsung Literasi keuangan kepada tiap indikator. Berdasarkan hasil efek langsung literasi keuangn yang memiliki pengaruh terbesar adalah investasi. Terdapat efek langsung dan tidak terdapat efek tidak langsung antara hasil belajar akuntansi kepada literasi keuangan

Keadaan ini juga sesuai dengan Penelitian terdahulu Sulaeman (2012) menyimpulkan bahwa hasil belajar tidak berpengaruh terhadap literasi keuangan. Tidak adanya pengaruh signifikan dalam penelitian ini dapat disebabkan oleh berbagai faktor.

Berdasarkan hasil pengamatan yang ada dilapangan hasil belajar akuntansi pada SMK PGRI 3 Sidoarjo dilihat dari nilai UAS Akuntansi. Hasil belajar akuntansi siswa kelas XI Akuntansi berada diatas nilai KKM (Ketuntasan kriteria Minimum). Berdasarkan hasil pembahasan hasil belajar akuntansi siswa tergolong pada kelas sedang. Walaupun hasil belajar berada diatas KKM (Kriteria Ketuntasan Minimu) tetapi nilai ini berada di bawah rata-rata nilai keseluruhan . Hasil belajar ini menunjukan kemampuan siswa dalam menerima pembelajaran disekolah. Hasil belajar yang baik maka akan menunjukkan kemampuan literasi keuangan yang baik.

Kita tidak bisa menutup mata pada saat ini, pada fenomena-fenomena yang terjadi pada dunia pendidikan bahwa hasil belajar tidak mencerminan hasil belajar 
yang sesungguhny, artinya hasil belajar sebagai pencerminan penguasaan kompetensi dasar tidak selaras dengan pengaplikasian dalam kehidupan serharihari.

Ada beberapa alasan mengapa hasil belajar tidak dapat ditransfer dalam penggunaan aktual. Pertama selama ini guru dalam mengajar sebenarnya sudah memiliki perangkat pembelajaran yang lengkap dan bagus, namun saat proses pembelajaran masih sering menekankan transfer pengetahuan yang bersifat informasi. Kondisi ini pada akhirnya menyebabkan siswa hanya mampu mengungkap kata-kata yang dihafalkan dari buku pelajarannya tetapi tidak dapat menggunakan dalam situasi baru.

Menurut Arifin mengatakan apabila suatu hasil belajar tidak dapat ditransfer dan hanya dapat digunakan dalam situasi tertentu saja, maka hasil belajar itu disebut hasil belajar palsu. Sebaliknya, jika suatu hasil belajar dapat ditransfer kepada penggunaan yang actual, maka hasil belajar itu disebut hasil belajar autentik. Jadi evaluasi yang baik harus mengukur hasil belaja yang autentik dan kemungkinan dapat ditransfer. Dalam penelitian sering ditemui hasil belajar yang dicapai tampaknya baik, tetapi sebenarnya hasil belajar itu palsu. Peserta didik hanya dapat mengucapkan kata-kata yang dihafalkan dari buku pelajarannya, tetapi mereka tidak dapat menggunakannya dalam situasi baru. Penguasaan mata pelajaran seperti ini tidak lebih dari penguasaan beo, yang ada pada akhirnya peserta didik hanya memiliki pengetahuan yang bersifat informative, belum tentu menjamin pemahaman dan pengertiannya untuk aplikasikan dalam kehidupan.

Kedua, dilihat dari segi siswa, selama ini siswa tidak memahami makna dari suatu nilai hasil belajar, mereka menggangap bahwa dengan nilai yang bagus mereka adalah anak pandai dalam tanda kutip. Anggapan seperti ini memang tidak selamanya salah., karena memang selama ini sekolah lebih mengedepankan nilai hasil belajar yang memenuhi standart KKM tanpa memperhatikan apakah nilai itu sudah mencerminkan kemampuan siswa untuk mentransfer ilmu pengetahuan yang mereka terima dari sekolah dalam situasi yang fungsional. Sehingga sering ditemukan dilapangan siswa berupaya untuk mendapatkan nilai yang bagus melalui jalan mencontek dan bekerjasama dengan teman demi mendapatkan nilai yang bagus dan pada akhirnya nilai bagus yang ia peroleh tidak bisa mencerminkan kemampuan mereka sesungguhnya serta tidak berpengaruh pada kemampuan mereka untuk mengaplikasikan konsep dasar ilmu ekonomi yang mereka terima dari sekolah.

Dari uraian di atas mengandung arti bahwa hasil belajar akuntansi siswa yang bagus tidak menjamin bahwa siswa tersebut mampu mengaplikasikan perilaku-perilaku seperti ini: pada saat melakukan penganggaran uang, melakukan pinjaman saat kekurangan, saat diperlukan melakukan mengurangi, melakukan investasi dengan barang yang dimilikinya, mengutamakan membeli barang yang sesuai dengan skala prioritas, membeli alat tulis dikopsis untuk mendukung pengembangan usaha kopsis dan bila ada uang saku akan ditabung

Penelitian ini tidak sesuai dengan penelitian terdahulu Ayu Khrisna (2012), Muizatul (2013) mengatakan bahwa IPK memiliki pengaruh terhadap literasi keuangan mereka.

Fenomena diatas merupakan beberapa penyebab mengapa seseorang yang hasil belajarnya bagus tetapi tidak bisa dijadikan jaminan bahwa seorang siswa 
dengan hasil belajar yang baik mampu mengaplikasikan dalam situasi yang relevan dengan kehidupannya.

\section{SIMPULAN}

1. Ada pengaruh signifikan negatif pembelajaran pengelolaan keuangan orang tua terhadap hasil belajar akuntansi siswa SMK PGRI 3 Sidoarjo.

2. Tidak ada pengaruh signifikan uang saku terhadap hasil belajar akuntansi siswa SMK PGRI 3 Sidoarjo.

3. Tidak ada pengaruh signifikan pembelajaran pengelolaan keuangan orang tua terhadap literasi keuangan siswa SMK PGRI 3 Sidoarjo.

4. Ada pengaruh signifikan negative uang saku terhadap literasi keuangan siswa SMK PGRI 3 Sidoarjo.

5. Tidak ada pengaruh signifikan hasil belajar akuntansi terhadap literasi keuangan siswa SMK PGRI 3 Sidoarjo.

\section{DAFTAR RUJUKAN}

ASIC ,2011.Financial Literacy and Behavioural Change. Australian Securities and Investment Commisions

Astuti. 2012. "Pengaruh Kemandirian belajar dan penggunaan uang saku terhadap prestasi belajar kompetensi dasar ekonomi kelas VII dan VII". Vol 1 No 2. journal . unnes.ac.id

Buntaran,Rina. 2004. Agar anak pandai mengelola uang panduan praktis untuk mengajar anak menabung, membelanjakan, dan mengivestasikan uangnya dengan benar. Jakarta: Gramedia

Cude et al ,2006. Collage Student \& Financial Literacy : What They Know and what the need. Eastern Family Economic and Resource Management Association.

Huda, Ainil.2007. Pengaruh teman sebaya, disiplin belajar,dan motivasi belajar terhadap hasil belajar ekonomi siswa kelas x di SMA Negeri1 Lembah Melintang Kabupaten Pasaman Barat.

Huston, Sandra J Measuring Financial Literacy. The Journal of Consumer Affairs, Summer 2010, Volume 44(2), pages 296-316.

Jorgensen.BL. 2007. "Financial Literacy of College Student: Parental and Peer Influence. Thesis Master of Sains in Human Development.Virginia

Krisna,Ayu, dkk. 2010. Analisis Tingkat Literasi Keuangan di kalangan mahasiswa dan faktor-faktor yang mempengaruhinya - survey pada mahasiswa Universitas Pendidikan Indonesia

Lisa Hadija. 2013. Pengaruh Teman Sebaya dan Prestasi belajar Ekonomi pada perilaku konsumsi siswa SMA khadijah Surabaya. Jurnal ekonomi pendidikan dan kewirausahaan. Vol.1 no 2 oktober 2013. Hal 186-196.

Mutsainah,Muizzatul. 2013. "Pengaruh Modernitas Siswa Dan Hasil Belajar Ekonomi terhadap Economic Literacy siswa di SMPN 3 Peterongan Jombang". Jurnal ekonomi pendidikan dan kewirausahaan. Vol.1 no 2 oktober 2013. Hal 109-120.

Nidar, Sulaeman R. and Sandi Bestari, 2012. "Personal Financial Literacy Among University Students (Case Study at Padjadjaran University Students, 
Bandung, Indonesia)". World Journal of Social Sciences Vol. 2. No. 4. July 2012. Pp. $162-171$

Remund. 2010. "Financial Literacy Explicated: The Case For A Clearer Definition In An Increasingly Complex Economy". The Journal Of Consumer Affairs. volume 44, number 2.

Sina dan Ida. 2012. "Financial literacy and cognitive style On Entrepreneurial Intentions". Global Network Journal - Vol. 5 No. 2 August 2012. Pp 230251

Slameto. 2010. Belajar dan faktor - faktor yang mempengaruhinya. Jakarta : Rineka cipta

Stephanie.W. 2011. Parental Influence on The Financial Literacy of Their School-Aged Children:An Exploratory Study.

Susanti. 2013."Faktor-faktor yang mempengaruhi literasi Keuangan Mahasiswa Fakultas Ekonomi Universitas Negeri Surabaya". Jurnal Ekonomi Bisnis. ISSN 0853-7283. Thn 18 No 1 Maret 2013. PP 89-96

Program Pascasarjana Unesa Universitas Negeri Surabaya. 2014. Pedoman Penulisan Tesis Dan Desertasi. Surabaya

Wahyono. 2001. Pengaruh Perilaku Ekonomi Kepala Keluarga Terhadap Intensitas Pendidikan Ekonomi di Lingkungan Keluarga (Desertasi tidak dipublikasikan). Universitas Negeri Malang,Malang.

Warsono. 2010. Prinsip-prinsip dasar dan keuangan Pribadi. Jurnal salam. Volume 13 Nomor 2 Juli - Desember 2010

Widiyati, Irin. 2011.Pengaruh Status Sosial Ekonomi Orang tua, Pendidikan Pengelolaan Keluarga, dan Pembelajaran di Perguruan Tinggi terhadap Literasi Finansial Mahasiswa Fakultas Ekonomi Universitas Brawijaya (Tesis tidak dipublikasikan). Universitas Negeri Malang, Malang.

Widiyati, Irin. (2012). "Faktor-faktor yang mempengaruhi literasi financial mahasiswa fakultas ekonomi dan bisnis universitas negeri Surabaya". Jurnal akuntansi dan pendidikan. Vol 1 no 1 okt 2012 